\title{
AXIOLOGY OF HUMAN RIGHTS. ON THE PREMISES AND DETERMINANTS OF CONTEMPORARY DISCOURSE IN THE PHILOSOPHY OF INTERNATIONAL LAW
}

\author{
Anna Kociołek-Pęksa, Jerzy Menkes \\ The Main School of Fire Service, The Faculty of Civil Safety Engineering \\ Warsaw School of Economics, Collegium of World Economy
}

\begin{abstract}
Considering the pluralism of the axiological sources of human rights, we claim that it is necessary to realize that we are facing at the moment an analytic extension of both the "number" of human rights (appearance of new generations of human rights), as well as the "quantitative quality" of human rights due to newly uncovered axiological sources such as the appearance of new values or a redefinition of existing ones. In the presented context of the axiology of human rights and the axiology of their protection, it is easy to observe the axiological pluralism of the two spheres as well as numerous attempts to make the exegesis and interpretation both relative and instrumental ${ }^{1}$ in a domestic, European, and international sphere. Attempts to limit human rights in a camouflaged manner in the jurisdiction practice of particular states are quite abundant and an axiological justification of legal solutions that would make the implementation and protection of those rights (in particular those of the third, fourth and fifth generations) ineffectual-de facto (not de iure, since from a formal and legal point of view they correspond to declared rights and, without exception, the protected ones) is the guarantee of community security and, paradoxically, the protection of other people (i.e., the protection of religious sentiments, family, public morality based usually on the rules of the dominant religion). When transposing these problematics from the state perspective to the intra- and trans-state level, we need to demonstrate that in the international law of protection of human rights, limitation of these rights may also take place as a result of extra-normative factors due to so-called "instrumental relativism", applied in the function of current political interests for which intrinsic human dignity happens to be infringed. We also claim that the active factor of that critical crossing point is not faults in the law or its interpretation, nor is it faults of ethics, but rather the faults of what is going on within so-called Realpolitik ${ }^{3}$.
\end{abstract}

1 Instrumentalisation of the law has two meanings: a neutral notion, and the notion biased by judgement (political instrumentalisation). The instrumentalisation of the law can be performed by: the legislator, the interpreter, the subject applying the law and legal doctrine. Typical forms of instrumentalisation of the law are made on account of law-external and law-uncoordinated goals, or by reinterpretation of norms (especially norms-rules) or of ideological assumptions of the system. We may also distinguish instrumentalisation exerted by infringement of norms defining the system of making and applying the law (infringement of institutional values of the system).

2 This term is used by J. Zajadło. Among the kinds of limitations on human rights we count the use of torture on terrorists to extract information apt to save the lives and health of citizens of a given country or on kidnappers to draw out information on the location of the victim. ZAJADŁO, J. Uniwersalizm praw człowieka w konstytucji - bezpieczne i niebezpieczne relatywizacje. "Przegląd Sejmowy" 2007, no. 4, pp. 98, 102 and next.

3 This idea is presented in ZAJADŁO, J. Po co prawnikom filozofia prawa? Oficyna a Wolters Kluwer business, Warszawa 2008 , p. 134. A distinct view is presented by M. Bothe, who in his comment on the Kosovo intervention, wrote: "When it comes to a collision between the law and ethics, then something must be wrong, whether with the law or with the ethics". BOTHE, M. In WALL, A.E. (ed.) Legal and Ethical Lessons of NATO's Kosovo Campaign, International Law Studies, Vol. 78, Naval Law College, Newport, Rhode Island 2002, p. 427. Quoted after J. Zajadło, therein, footnote no. 124. 
Key words: international law of human rights, new generations of human rights, axiological foundation of human rights, legal philosophy of human rights protection, political philosophy

Inseparable from the axiology of human rights ${ }^{4}$ is the identification of the human being as the subject of the law ${ }^{5}$. In the normative perspective, it is assumed that a human being is the subject of the law only within the range of legal subjectivity granted by legal norms ${ }^{6}$ while his/her rights as a human are universal ${ }^{7}$ and inalienable and cannot be in any aspect conditioned by legal subjectivity. At the same time, the nonnormative perspective assumes that a human being, an individual, is the subject of international law and the international law of human rights per se. The road to this axiom goes from Professor Berezowski's ideas (one who is not the subject of international law is its object, which a contrario led to the conclusion that a human being is the subject of the international $\mathrm{law}^{8}$ ) to as far as the conviction stemming from the experience of the "destruction" of Scelle's concept that a human being is the only subject of international law (while the state is his legal agent) ${ }^{9}$. According to this latter view, a human being ${ }^{10}$ constitutes in the eyes of the state and of the legal order, an autotelic value-goal, the same as in moral philosophy, and it is a good worth pursuing, nourishing, and protecting. To avoid discussion about the justification for special treatment of a human being by the law, every legal and political concept should be based on a comprehensive but culturally neutral, axiological definition of a human being ${ }^{11}$. In the system of international law of human rights, a human being becomes the subject of legal protection in a way exempt from any ex-

4 Obviously, there are many concepts and definitions of human rights and some authors even attempt to formulate a multidiscipline synthesis in their definitions of human rights; for more, see WAŚKIEWICZ, H. Prawa człowieka, pojęcie, historia. "Chrześcijanin w świecie" 1978 (10, Nos. 3-4.). See also: Franciszek J. Mazurek, who formulates his own definition after a thorough analysis of the ways of understanding human rights. In his view, "(...) human rights [are] (...) all the subject rights, beyond-systemic - natural — read from the inherent dignity of a human being with its correspondent duties; which are proclaimed in Constitutions and international law, taking the form of positive laws without losing anything of their natural character of moral law, they distinguish themselves by universality, inalienability and dynamics, responding to human dignity and protect it both vertically and horizontally", MAZUREK, F.J. Godność osoby ludzkiej podstawą praw człowieka. Redakcja Wydawnictw Katolickiego Uniwersytetu Lubelskiego. Lublin, 2001. p. 195.

5 The legal-theoretical literature seeks an answer to the question whether the subject of the law is a human being or a natural person. For more, see CHAUVIN, T. Osoba fizyczna czy człowiek? Kilka refleksji na temat podmiotu prawa. “Principia” LXI-LXII (2015), pp. 123-139. Doi: 10.4467/20843887PI.15.007.5536. See also: CHAUVIN, T. Homo iuridicus. Człowiek jako podmiot prawa publicznego. Wydawnictwo C.H. Beck. Warszawa, 2014. A natural person is a model vision of a healthy, adult human being who expresses his will freely and consciously. See BROŻEK., B Pojęcie osoby w dyskusjach bioetycznych. In STELMACH, J. - BROŻEK, B. - SONIEWICKA, M. - ZAŁUSKI, W. Paradoksy bioetyki prawniczej. Wydawnictwo Wolters Kluwer. Warszawa, 2010, p. 52.

6 This conviction is reconstructed on two concepts: naturalistic and normative. See BOSEK, L. Gwarancje godności ludzkiej i ich wpływ na polskie prawo cywilne. Wydawnictwo Sejmowe, Warszawa, 2012, pp. 271-274.

7 An array of documents produced during the UN's work and stemming from reports of the High-Level Panel from 2004, from the UN General Secretary on the $21^{\text {st }}$ of March 2005, and from the World Summit of the $15^{\text {th }}$ of September 2005, contain the standpoint confirming the thesis of the universal character of human rights.

8 BEREZOWSKI, C. Les sujets non souverains du droit international. Recueil de cours. Academie de droit international 1938 (III), Vol. 65, pp. 6-82, in particular pp. 14-20.

9 SCELLE, G. Manuel de droit intenational public. Paris 1948.

10 The equivalent for the word "man" in international documents on human rights is the expression "human being" or "human person", often treated as substitutes, which probably can be explained by the translation from the original languages of those texts.

11 So: BARANKIEWICZ, T. Filozoficzne uzasadnienie praw człowieka w kontekście procesu globalizacji. In STELMACH, J. (ed.). Filozofia prawa wobec globalizmu. Wydawnictwo Uniwersytetu Jagiellońskiego w Krakowie. Kraków, 2003 , p. 52 and next; CHAUVIN, T. Osoba fizyczna czy człowiek? Kilka refleksji na temat podmiotu prawa. "Principia" LXI-LXII (2015), p. 128. Doi: 10.4467/20843887PI.15.007.5536. 
ception ${ }^{12}$ in the formal and legal aspect. Within competing, or even antonymic values (i.e., freedom and security), that sit at the foundation of human rights and the system of protection of those rights, it is indispensable for international law actors to maintain constant efforts aimed at the achievement, guarantee and protection of a homeostatic balance between the implementation of the values and laws in the system of protection of human rights. This homeostasis should be maintained both in relation to the axiological foundation of human rights and the legal system of their protection in genere, as well as with respect to particular legal institutions of protection in specie. Considering the pluralism of the axiological sources of human rights, it is necessary to realize that we are facing at the moment an analytic extension of both the "number" of human rights (appearance of new generations of human rights), as well as the "quantitative quality" of human rights due to newly uncovered axiological sources such as the appearance of new values or a redefinition of existing ones. In the field of philosophy of the law, and in the philosophy of international law in particular, it has been demonstrated that particular generations of human rights may be selected based on a criterion of the implementation of given ideas/values. Thus, the first generation of human rights came from the value of personal dignity and freedom, which it is supposed to implement to the greatest extent. The second generation focused on the value of equality-distributive and compensating justice. In the case of the third generation of human rights, the goal (after the end of the Cold War) was the accomplishment of the idea of solidarity ${ }^{13}$. The next one, shaped also in the $20^{\text {th }}$ century, was the fourth generation of human rights ${ }^{14}$ also called "new human rights"15, which stems from the idea of tolerance for individuals belonging to defined social minorities (religious, ethnic, sexual orientation, etc.). According to Zajadło, however, we may very well distinguish a fifth generation of human rights whose source is a specifically /untraditionally comprehended human dignity. He believes that this dignity stems from the psycho-physical structure of every man as well as from biochemical and neuronal-cognitive processes taking place in the human brain. Thus, we consider the source of the fifth generation of human rights to be the findings of research on human dignity made in contemporary biojurisprudence that perceives a human being as a person ${ }^{16}$. The percep-

12 To indicate that these are subject rights requires for them to be distinguished from object rights. For more on that distinction in the international protection of human rights, see WAŚKIEWICZ, H. Prawa człowieka, pojęcie, historia. "Chrześcijanin w świecie" 1978, p. 14-20.

13 We are leaving aside the original, political motives of the concept of human rights of the third generation, which came from the East-West confrontation and were aimed at weakening the human rights of the first generation through the help of developing countries and UNESCO. And even though the original goal was dishonest, these rights (more for collectives than individuals) developed as complementary to human rights of the first and second generation.

14 We can encounter as well, a restricting and reductive comprehension of the fourth generation of human rights, postulated mostly by Catholic thinkers who reduce these generations of rights solely to the protection of the right to life for all human beings without any distinction, from the moment of conception to natural death (without precepting, however, the use of aggressive life-maintaining therapies). This new generation in the evolution of human rights is a response to the dynamic progress in bio-medical technologies that interfere deeper and deeper with the structure of human life at its very core. For more, see COMPAGNONI, F. Prawa człowieka. Geneza, historia i zaangażowanie chrześcijańskie. Wydawnictwo WAM. Kraków, 2000, pp. 265-270.

15 For more on that still-unrecognized new category of human rights, see CLIFFORD, B. Introduction. Fighting for a New Rights. In CLIFFORD B. (ed.). The International Struggle for New Human Rights. University of Pennsylvania Press. Philadelphia, 2009. The author describes, among others, the procedure of recognition of new law as a human right, that is, composed of four separate actions. Same, p. 4.

16 For more on the notion of "a human being" as a person and a person as a legal category, see BROŻEK., B Pojęcie osoby w dyskusjach bioetycznych. In STELMACH, J. - BROŻEK, B. - SONIEWICKA, M. - ZAŁUSKI, W. Paradoksy bioetyki prawniczej. Wydawnictwo Wolters Kluwer. Warszawa, 2010; BRECZKO, A. Podmiotowość prawna człowieka w warunkach postępu biotechnomedycznego. Wydawnictwo Temida 2. Białystok, 2011, p. 162 and next. 
tion of the following generations of human rights, shows signs of paradox thinking. The essence of the third generation of the human rights was rejection of the primacy of the individual (the foundation of Western political civilization) in favor of a group-collectivity closer to the culture of the South but also complying with Catholic social teachings from before the era of John Paul II and with so-called Marxism (that is, a reflection of the party in the Soviet Union and countries of the former Eastern Bloc) ${ }^{17}$. Consequently, the key categories of human rights of the third generation were "peoples", "nations", and occasionally "humanity", but not the individual. It was only in the fourth generation of rights that its authors attempted, thanks to intellectual acrobatics, to combine group rights with those of individuals. Attractive packaging for those procedures came in the form of the rights of an individual belonging to a (negatively) discriminated social group, connected with the rights of that group as a whole.

In the above-presented context of the axiology of human rights and the axiology of their protection, it is easy to observe the axiological pluralism of the two spheres as well as numerous attempts to make the exegesis and interpretation both relative and instrumental ${ }^{18}$ in a domestic, European, and international sphere. Attempts to limit human rights in a camouflaged manner in the jurisdiction practice of particular states are quite abundant and an axiological justification of legal solutions that would make the implementation and protection of those rights (in particular those of the third, fourth and fifth generations) ineffectual-de facto (not de iure, since from a formal and legal point of view they correspond to declared rights and, without exception, the protected ones) is the guarantee of community security and, paradoxically, the protection of other people (i.e., the protection of religious sentiments, family, public morality based usually on the rules of the dominant religion). When transposing these problematics from the state perspective to the intra- and trans-state level, we need to demonstrate that in the international law of protection of human rights, limitation of these rights may also take place as a result of extra-normative factors due to so-called "instrumental relativism"19, applied in the function of current political interests for which intrinsic human dignity happens to be infringed. Therefore, it is inevitable in the given circumstances to ask an obvious question about the axiology of the legal actions in the field of the protection of human rights and common security. What would be the alternatives to legal or legitimized ${ }^{20}$ actions given an infringement of human rights,

17 For example, in Poland, the party directed a pseudo-scientific attack on Schaff's theory (SCHAFF, A. Alienacja jako zjawisko społeczne. Wydawnictwo Książka i Wiedza. Warszawa, 1999.) through a book by Chałasiński (CHAŁASIŃSKI, J. Społeczeństwo i wychowanie, Państwowe Wydawnictwo Naukowe. Warszawa, 1969). The author pitted the well-rooted peasant class against cosmopolitan individuals-behind this "March gag", he was pointing at Jews. The attack was part of wider anti-Semitic actions.

18 Instrumentalisation of the law has two meanings: a neutral notion, and the notion biased by judgement (political instrumentalisation). The instrumentalisation of the law can be performed by: the legislator, the interpreter, the subject applying the law and legal doctrine. Typical forms of instrumentalisation of the law are made on account of law-external and law-uncoordinated goals, or by reinterpretation of norms (especially norms-rules) or of ideological assumptions of the system. We may also distinguish instrumentalisation exerted by infringement of norms defining the system of making and applying the law (infringement of institutional values of the system).

19 This term is used by J. Zajadło. Among the kinds of limitations on human rights we count the use of torture on terrorists to extract information apt to save the lives and health of citizens of a given country or on kidnappers to draw out information on the location of the victim. ZAJADŁO, J. Uniwersalizm praw człowieka w konstytucji - bezpieczne i niebezpieczne relatywizacje. "Przegląd Sejmowy" 2007, no. 4, pp. 98, 102 and next.

20 This is about the legal and axiological dimensions of these actions that assume an action that is illegal or discordant with the legal regime may be simultaneously axiologically legitimized legally and extra-legally. For more on legality and legitimisation in the law and associated ambiguities, see MENKES, J. - KOCIOŁEK-PĘKSA, A. Correlation between legitimacy and legalism—selected problems. "The Polish Review of International and European Law", PRIEL Vol. 5, No. 1 (2016). 
insufficient negative opinion from the international community, or dysfunction in the decision process of the UN Security Council ${ }^{21}$ that would be acceptable to the international community? In our quest for an answer for that question, we find a few possible solutions. "Specialists of international law, well aware of the dilemma, more and more often give the following answer: let's observe the letter of the law and put the rule of sovereignty of states and the system of common security above human rights; or, in the process of interpretation of the UN Charter and of other Conventional and usual norms, let's accept the possibility of humanitarian intervention based on international law; or else, let's take such a situation as an extreme normative exception that gives permission to incidental infringement of the abiding law; or, finally, let's break international law to conduct radical reform of it and let's make the unilateral humanitarian intervention legal"22. A choice of any of these options, however, would have to take into account the type of endangered or infringed value or of particular human rights. The type of threat as well as the manner and range of infringement, together with its intensity and permanency, will in a given situation determine the choice of one of the above-mentioned solutions. The adopted solution probably won't be based on moral philosophy, axiology, ethics, or philosophy of the law, but rather on the up-to-date overwhelming presence of threats and breaches following terrorist acts (with unjustified downgrading of the size of infringements related to human trafficking for instance). It will be based at best, on the philosophy of politics.

The current discourse on human rights vis-à-vis terrorism ${ }^{23}$ - considered to be the most serious threat to the implementation of the former-is being transferred to the sphere of political philosophy, which by its nature is a normative discipline and refers to an axiology deprived of absolute character. Human rights examined in light of the science of the law, moral philosophy or ethics and faced with the axiology of terrorism become more and more defenseless as far as their axiological justification is concerned. This is the same in the case of the law in light of positivism, since it sets up a thesis about the neutral nature of the law according to which the theory of law is only descriptive and therefore doesn't aim at any formulation of an axiological justification or recommendation. What seems to be essential in this context is the question formulated by T. GizbertStudnicki whether indeed the positivist theories of the law are not forced to adopt (even within the so-called "inside point of view") certain assumptions belonging to political philosophy, which invokes values, and these are always involved with politics ${ }^{24}$. The author of this question postulates

21 It is worth remembering that the use of force to protect human rights should be conducted according to the rules and procedure described in the UN Charter, that is, backed by a UN Security Council decision granted a priori. Nevertheless, there have been cases of the use of force to protect human rights without a positive decision by the UN Security Council, such as the NATO intervention in Kosovo, which despite it all is still considered legitimate by the international community, and successively, by the Independent International Commission on Kosovo. "The Commission acknowledges that the NATO military intervention in Kosovo was illegal but legitimate", states the report by the commission. See The Kosovo Report. Conflict, International Response, Lessons Learned, Oxford University Press, Oxford 2000, p. 4; and Menkes, J. The Kosovo situation-international law aspects. ILA Newsletter no. 13. March 2000.

22 ZAJADŁO, J. Po co prawnikom filozofia prawa? Oficyna a Wolters Kluwer business. Warszawa, 2008, p. 104 along with the quoted bibliography.

23 The literature on the subject increasingly is of the opinion that international terrorism is currently one of the most serious threats to human rights. STANKIEWICZ, W. Terroryzm a prawa człowieka, “Gdańskie Studia Prawnicze” 2005, Vol. 13, pp. 455 and next.

24 The question was formulated by T. Gizbert-Studnicki in his paper: Filozofia polityczna a pozytywistyczna teoria prawa, read during the XXII Congress of Departments of Theory and Philosophy of the Law, Wrocław, September 2016. A written version of the speech has not yet been published. http://www.humanitas.edu.pl/resources/upload/dokumenty/Wydawnictwo/Roczniki\%20AiP\%20-\%20pliki/Podzielone/Rocznik\%20AiP\%202016\%20z\%202/26.Kalisz-2016-2-480-486.pdf, (accessed: 2017. 06. 15). 
regarding the positivist theory of law as a type of "minimum theory", one that fails to give answers to many of the most important philosophical and legal questions and, what is more, is incapable of elucidating the normative character of the law or constructing a satisfying theory of adjudication ${ }^{25}$. The link between contemporary jurisprudence in general and the discourse and dialectics of human rights in particular within the category of politics is not only a fact but also is discernable in two aspects: first, the involvement of jurisprudence in current politics makes it an instrument of a political battle, which from a scientific point of view seems neither right nor advisable (politicization of science); and second, the perception of necessary relations between the law and politics without simultaneous participation in current political conflicts, which from the point of view of external and internal integration of jurisprudence seems to be both right and advisable science of politics) ${ }^{26}$. A scientist (within cognitive theory based on discursive intellect and not on intuitive cognition through "experience") is practically unable to remain absolutely impartial. His lack of impartiality, however, does not imply a lack of objectivism or a release from the duty of maintaining the principle of discursive argumentation. Everyone who takes part in the debate on human rights and their protection does so within well-defined political aspects of time and place, which makes the discourse political. Also determining are the socializing processes of every participant of that discourse, coming from, for instance, empirical experience of a lack of possibilities to implement, limit, or break his or her human rights (or even, in a "lighter version", the rights of a citizen). In the axiology of human rights, the critical point is a meshing of the legal plain (discourse) with the ethical plain (discourse). The active factor of that critical crossing point is not faults in the law or its interpretation, nor is it faults of ethics, but rather the faults of what is going on within so-called Realpolitik ${ }^{27}$.

In reference to the conglomeration of generations of human rights we discussed earlier, the two "youngest" generations appear to be crucial. These would be: extracted as a category of collective human rights and defined as the fourth generation, as well as the fifth due to the intensification of research in the field of biojurisprudence and neuroscience. The core meaning of fourth generation rights differs fundamentally from the core of contemporary categories (that is, from the human rights of the first and second, but also third generations). The reason for it is a shift in their focus, from the accent put on social or political entitlements or collectivity rights to the emphasis put on questions of worldviews and ethics. This category of rights will dominate the moral, ethical, legal, and political discourse as to what they really are and how to effectively ensure and protect them, and how to successfully enforce the human rights protection regime as it pertains to various groups (i.e., migrants, LGBTQ). It is to be supposed that a theoretical, philosophical, and legal-dogmatic redefinition of the values at the foundation of human rights, particularly those of the fourth and fifth generations, is inevitable. The problems at an international social and legal scale that will play the role of "detonator" of this process is the worsening crisis of mass migration, refugees, nationalism, authoritarian systems and terrorism, towards which the dialectics of human rights used un-

25 Ibidem.

26 ZAJADŁO, J. Prawoznawstwo-polityczność nauki czy nauka polityczności? XXII Congress of Departments of Theory and Philosophy of the Law, Wrocław, September 2016. A written version of the speech has not yet been published.)

27 This idea is presented in ZAJADŁO, J. Po co prawnikom filozofia prawa? Oficyna a Wolters Kluwer business, Warszawa 2008, p. 134. A distinct view is presented by M. Bothe, who in his comment on the Kosovo intervention, wrote: "When it comes to a collision between the law and ethics, then something must be wrong, whether with the law or with the ethics". WALL, A.E. (ed.) Legal and Ethical Lessons of NATO's Kosovo Campaign, International Law Studies, Vol. 78, Naval Law College, Newport, Rhode Island 2002, p. 427. Quoted after J. Zajadło, therein, footnote no. 124. 
til now are no longer adequate for the political, legal, and social reality, but also dysfunctional in their emptiness and repetitiveness of outdated and ill-fitting diagnoses and conclusions, and-as we have seen-remedial means. The fifth generation of rights, in turn, will largely depend on the real influence discoveries made in neuroscience and biojurisprudence will have on other branches of law and other scientific disciplines, especially in political science, security science, and philosophy sensu largo.

\section{Bibliography:}

BARANKIEWICZ, T. Filozoficzne uzasadnienie praw człowieka w kontekście procesu globalizacji. In STELMACH, J. (ed.). Filozofia prawa wobec globalizmu. Wydawnictwo Uniwersytetu Jagiellońskiegio w Krakowie. Kraków, 2003.

BEREZOWSKI, C. Les sujets non souverains du droit international. Recueil de cours. Academie de droit international 1938 (III), Vol. 65.

BOSEK, L. Gwarancje godności ludzkiej i ich wpływ na polskie prawo cywilne. Wydawnictwo Sejmowe. Warszawa, 2012.

BRECZKO, A. Podmiotowość prawna człowieka w warunkach postępu biotechnomedycznego. Wydawnictwo Temida 2. Białystok, 2011.

BROŻEK B. Pojęcie osoby w dyskusjach bioetycznych. In STELMACH, J. - BROŻEK, B. - SONIEWICKA, M. ZAŁUSKI, W. Paradoksy bioetyki prawniczej. Wydawnictwo Wolters Kluwer, Warszawa, 2010.

CHAUVIN, T. Homo iuridicus. Człowiek jako podmiot prawa publicznego. Wydawnictwo C.H. Beck. Warszawa, 2014.

CHAAUVIN, T. Osoba fizyczna czy człowiek? Kilka refleksji na temat podmiotu prawa. "Principia” LXI-LXII (2015), pp. 123-139. Doi: 10.4467/20843887PI.15.007.5536.

CHAŁASIŃSKI, J. Społeczeństwo i wychowanie. Państwowe Wydawnictwo Naukowe. Warszawa, 1969.

CLIFFORD, B. Introduction. Fighting for a New Rights. In CLIFFORD, B. (ed.) The International Struggle for New Human Rights. University of Pennsylvania Press, Philadelphia, 2009.

COMPAGNONI F. Prawa człowieka. Geneza, historia i zaangażowanie chrześcijańskie. Wydawnictwo WAM. Kraków, 2000.

GIZBERT-STUDNICKI, T. Filozofia polityczna a pozytywistyczna teoria prawa. XXII Congress of Departments of Theory and Philosophy of the Law, Wrocław, September 2016. A written version of the speech has not yet been published. http://www.humanitas.edu.pl/resources/upload/dokumenty/Wydawnictwo/Roczniki\%20AiP\%20-\%20 pliki/Podzielone/Rocznik\%20AiP\%202016\%20z\%202/26.Kalisz-2016-2-480-486.pdf, (accessed: 2017. 06. 15).

MAZUREK, F.J. Godność osoby ludzkiej podstawą praw człowieka. Redakcja Wydawnictw Katolickiego Uniwersytetu Lubelskiego, Lublin, 2001.

MENKES, J. KOCIOŁEK-PĘKSA, A. Correlation between legitimacy and legalism—selected problems. The Polish Review of International and European Law (PRIEL) Vol. 5, no. 1 (2016).

MENKES, J. The Kosovo situation-international law aspects. International Law Association Newsletter no. 13. March 2000.

SCELLE, G. Manuel de droit international public. Paris 1948.

SCHAFF, A. Alienacja jako zjawisko społeczne. Wydawnictwo Książka i Wiedza. Warszawa, 1999.

STANKIEWICZ, W. Terroryzm a prawa człowieka. “Gdańskie Studia Prawnicze” 2005, Vol. 13.

The Kosovo Report. Conflict, International Response, Lessons Learned, Oxford University Press, Oxford 2000.

WALL, A.E. (ed.). Legal and Ethical Lessons of NATO’s Kosovo Campaign. International Law Studies. Vol. 78, Naval Law College, Newport, Rhode Island 2002.

WAŚKIEWICZ, H. Prawa człowieka, pojęcie, historia. "Chrześcijanin w świecie” 1978 (10, Nos. 3-4.). 
ZAJADŁO, J. Prawoznawstwo-polityczność nauki czy nauka polityczności? XXII Congress of Departments of Theory and Philosophy of the Law, Wrocław, September 2016. A written version of the speech has not yet been published. http://www.humanitas.edu.pl/resources/upload/dokumenty/Wydawnictwo/Roczniki\%20AiP\%20-\%20pliki/ Podzielone/Rocznik\%20AiP\%202016\%20z\%202/26.Kalisz-2016-2-480-486.pdf, (accessed: 2017. 06. 15).

ZAJADŁO, J. Po co prawnikom filozofia prawa? Oficyna a Wolters Kluwer business. Warszawa, 2008.

ZAJADŁO, J. Uniwersalizm praw człowieka w konstytucji - bezpieczne i niebezpieczne relatywizacje. "Przegląd Sejmowy" 2007, no. 4 .

\section{Contact information:}

Dr. Anna Kociołek-Pęksa apeksa@dgsp.edu.pl

The Main School of Fire Service in Warsaw, The Faculty of Civil Safety Engineering ul. Słowackiego 52/54

01-629 Warsaw

Poland

prof. Jerzy Menkes

jmenkes@sgh.waw.pl

Warsaw School of Economics, Collegium of World Economy

al. Niepodległości 162

02-554 Warsaw

Poland 